\title{
HUBUNGAN PENGETAHUAN DAN TINGKAT KECEMASAN PADA KEHAMILAN PRIMIGRAVIDA DENGAN FUNGSI SEKSUAL DI KOTA BUKITTINGGI
}

\author{
Detty Afriyanti $S^{1}$,Ulfa Oktaviani ${ }^{2}$ \\ 1,2ProgramStudi Kebidanan, Universitas Fort De Kock, \\ email: afriyantidetty@gmail.com
}

Submitted: 20-12-2019, Reviewer: 25-12-2019, Accepted:30-12-2019

\begin{abstract}
Society in Indonesia considers sexuality a personal matter and is ashamed to be expressed. As many as 40-50\% of the female population experiences sexual dysfunction during their lifetime. This study aims to determine the Relationship between Knowledge and Anxiety Level in Primigravida Pregnancy with Sexual Function of First Trimester Pregnant Women in the Work Area of the Bukittinggi City Health Center in 2019.

The research design used was descriptive analytic study. Samples were 41 trimester I primigravida pregnant women. The samples used total sampling technique. Data collection was carried out by interview technique with aids in the form of a questionnaire. Timing of the study was conducted in March-June 2019. Data processing was computerized and used univariate analysis and bivariate analysis.

The results showed there was no relationship between knowledge and sexual function in primigravida pregnancy in trimester I pregnant women and there was a significant relationship between anxiety levels and sexual function in Primigravida Trimester I Pregnancy in Bukittinggi City Health Center in 2019.

It is expected that pregnant women will understand how to control the level of anxiety during pregnancy, so that it does not affect psychologically during the pregnancy period.
\end{abstract}

\begin{abstract}
Abstrak
Masyarakat di Indonesia menganggap seksualitas merupakan masalah pribadi dan malu diungkapkan. Sebanyak 40-50\% dari populasi wanita mengalami disfungsi seksual pada masa hidupnya. Penelitian ini bertujuan untuk mengetahui Hubungan Pengetahuan dan Tingkat Kecemasan pada Kehamilan Primigravida dengan Fungsi Seksual Ibu Hamil Trimester I di Wilayah Kerja Puskesmas Kota Bukittinggi Tahun 2019.

Desain penelitian yang digunakan adalah studi deskriptif analitik. Sampel sebanyak 41 ibu hamil primigravida trimester I. Sampel menggunakan teknik total sampling. Pengumpulan data dilakukan dengan teknik wawancara dengan alat bantu berupa kuesioner. Waktu Penelitian dilakukan pada bulan Maret-Juni 2019. Pengolahan data dengan komputerisasi dan menggunakan analisa univariat dan analisa bivariat.

Hasil penelitian menunjukkan terdapat Tidak terdapat hubungan antara pengetahuan dengan fungsi seksual pada kehamilan primigravida ibu hamil trimester I dan terdapat hubungan yang bermakna antara tingkat kecemasan dengan fungsi seksual pada Kehamilan Primigravida Trimester I di Puskesmas Kota Bukittinggi Tahun 2019.

Diharapkan kepada Ibu hamil untuk memahami cara pengendalian tingkat kecemasan pada masa kehamilan, sehingga tidak berpengaruhi kepada psikologis selama menajlani masa kehamilan.
\end{abstract}

Kata Kunci: Pengetahuan, Fungsi Seksual, Ibu Hamil, Kecemasan, Primigravida 


\section{PENDAHULUAN}

Seksualitas merupakan salah satu dari kebutuhan dasar manusia yang wajib dipenuhi, namun pada sisi lain berbagai permasalahan seksualitas masih menjadi hal yang sensitif dan jarang untuk dibicarakan secara umum. Apalagi masyarakat di Indonesia dengan budaya timur, masih banyak yang menganggap seksualitas merupakan masalah pribadi dan malu diungkapkan (Budiarti, dkk, 2012).

Perubahan fungsi seksual selama kehamilan memerlukan penyesuaian diri antara suami istri dan bahkan memerlukan bantuan tenaga profesional. Apabila kebutuhan seksual yang bersifat fisiologis dan dasar tidak terpenuhi maka akan menimbulkan masalah psikis bagi ibu hamil maupun pasangannya bahkan dapat memicu keretakan dalam rumah tangga hingga terjadinya perceraian. Fungsi seksual dipengaruhi oleh usia, pengetahuan, penyakit kronik, hormon seksual, kehamilan dan persalinan. Gangguan fungsi seksual dapat mempengaruhi kualitas hidup wanita dan memiliki efek negatif pada rasa percaya diri. Dalam sebuah populasi umum wanita dapat mengalami gangguan fungsi seksual sebesar 40-50\% selama hidupnya (Pangkahila, 2006).

Fungsi seksualitas terdiri dari 3 aspek yaitu desire (keinginan untuk berhubungan seks), arousal (perubahan fisik pada tubuh yang mengijinkan seseorang berhubungan seks) dan orgasme. Apabila satu dari tiga fungsi ini mengalami gangguan maka keadaan ini disebut difungsi seksual. Pada masa kehamilan, fungsi seksualitas wanita mengalami perubahan sesuai dengan usia kehamilannya. Hal ini disebabkan oleh perubahan hormonal wanita ketika hamil yang mempengaruhi keinginannya untuk berhubungan seksual. Sebanyak 40-50\% dari populasi wanita mengalami disfungsi seksual pada masa hidupnya. (Saraswati dan Pangkahila, 2018)

Masa kehamilan merupakan masa transisi dalam siklus kehidupan seorang wanita. Pada kehamilan, terjadi perubahan fisik seperti mual, muntah, perut yang membesar, cepat lelah dan nyeri payudara. Perubahan tersebut dapat menghilangkan gairah seks bagi salah satu atau kedua pasangan (Ramadani 2013). Selama trimester pertama kehamilan, progesteron merupakan penyebab utama perubahan fisik dan mental yang ikut mempengaruhi fungsi seksual pada ibu hamil. Hormon progesteron mempengaruhi kehidupan seksual secara negatif karena timbulnya rasa mual dan muntah. Hormon ini juga menyebabkan adanya vasodilatasi pada pembuluh darah yang dapat menyebabkan kelelahan dan perubahan emosiyang berhubungan dengan depresi. Trend perilaku seks pada ibu hamil adalah mengalami penurunan fungsi pada trimester pertama. Ibu hamil trimester pertama akan mengalami penurunan dorongan atau hasrat seksual. Hal ini disebabkan karena ibu belum beradaptasi dengan perubahan tubuhnya. Hapsari dan Sudarmiati dalam Ramadani 2013 menyatakan bahwa hasrat seksual ibu hamil menurun diawal kehamilan. Menurut Weiss dan Zverina (2009. Hubungan seks suami istri tidak dilarang dalam kehamilan. Walaupun hubungan seksual tidak dihalangi, namun pada trimester pertama wanita gravida 
seringkali merasa lelah, dengan penurunan libido (Prawirohardjo, 2007 dalam Fajrin, 2016).

Saat pria mengalami ejakulasi dan sperma masuk ke vagina, didalam sperma terdapat prostaglandin yakni hormon yang bisa menimbulkan kontraksi. Menurut Wimpie "bagian dari prostaglandin ini memang bisa menyebabkan kekejangan otot rahim meski konsentrasinya tak cukup besar untuk menimbulkan kekejangan. Justru kekejangan lebih sering dan lebih kuat karena orgasme". Jadi, selama tidak menjadi beban bagi istri, hubungan intim selama hamil tidak jadi masalah. Lain hal jika istri kehilangan dorongan seks dan hanya melakukan hubungan seks demi memuaskan suami, bisa-bisa hanya akan menjadi beban baginya (Wikjosastro, 2002 dalam Yogi 2016).

World

Health

Organization(WHO) menyatakan, seksualitas yang sehat menggambarkan hubungan dan integrasi yang positif antara kondisi fisik, emosional, intelektual dan seksual seorang individu dalam berbagai cara yang dapat memperkaya dan meningkatkan personalitas, komunikasi, dan cinta kasih seksual dirinya dalam menjalin hubungan dengan orang lain. Seorang pakar keperawatan menyatakan, Virginia Henderson menyatakan bahwa manusia memiliki 14 kebutuhan dasar hidup yang wajib dipenuhi untuk menjaga kelangsungan hidupnya. Seksualitas adalah salah satu komponen penting kebutuhan dasar manusia dari 14 kebutuhan dasar manusia tersebut. Kebutuhan seksual manusia diantaranya manusia membutuhkan kelembutan, hubungan kedekatan atau intimai dengan orang terdekat, tampil menarik didepan publik, mencintai dan dicintai, dan bereproduksi. Kebutuhan psikologis ibu jika tidak terpenuhi terutama kebutuhan seks saat hamil dapat mengakibatkan tekanan pada psikologis ibu dan dapat berdampak pada pertumbuhan dan perkembangan janin yang dikandungnya, kelahiran premature, dan keguguran (Widiasmoko, 2009 dalam permatasari, 2015).

Penelitian yang dilakukan oleh Puspita (2011) menyatakan bahwa ibu hamil yang mempunyai pengetahuan kurang biasanya tidak mengerti tentang batasan coitus (hubungan seksual) yang diperbolehkan saat kehamilan. Pengetahuan erat kaitannya dengan pendidikan, dimana pendidikan merupakan suatu proses belajar yang mengarahkan individu lebih dewasa dan lebih matang pemikirannya. (Nurymasari, dkk. 2017). Penelitian yang dilakukan oleh Hapsari dan Sudarmiati (2011) menyatakan bahwa hasrat seksual ibu hamil menurun diawal kehamilan karena libido ibu hamil menurun dan tubuh belum dapat beradaptasi dengan perubahan fisik yang dirasakan, meningkat pada trimester kedua karena libido ibu sudah mulai muncul kembali dan tubuh ibu hamil sudah dapat beradaptasi dengan perubahan tubuh, dan menurun kembali di trimester ketiga karena kelelahan akibat perut yang semakin membesar.

Siklus resppon seks pada wanita dipengaruhi oleh beberapa faktor yang kompleks dan saling berhubungan antara lain psikologis, lingkungan, dan fisiologis. Sehingga pengetahuan yang baik akan mempengaruhi tingkat kecemasan seseorang dimana pengertian, 
kehangatan, dan dukungan sangat dibutuhkan kedua belah (Wals, Linda $\mathrm{V}, 2008$ ). Dampak kecemasan saat hubungan seks saat kehamilan adalah semakin jarang frekuensi hubungaan seks pasangan, maka menyebabkan perkawinan semakin tidak sehat (Wikjosastro, 2002).

Berdasarkan penelitian yang telah dilakukan Yogi pada bulan Desember 2016 terhadap 45 orang ibu hamil yaitu $54,28 \%$ ibu mengalami kecemasan ringan dan berpengetahuan cukup sebanyak $57,12 \%$. Data literatur menyatakan bahwa disfungsi seksual dialami oleh sekitar 22-50\% perempuan. Disfungsi seksual perempuan didefinisikan sebagai gangguan fungsi seksual yang melibatkan satu atau beberapa fase dalam siklus respon seksual, atau nyeri yang berhubungan dengan aktivitas seksual. Disfungsi seksual pada wanita merupakan masalah kesehatan reproduksi yang penting karena berhubungan dengan kelangsungan fungsi reproduksi seorang wanita dan berperngaruh besar terhadap keharmonisan hubungan suami istri.Disfungsi seksual seringkali tidak disadari baik oleh pasien maupun klinisi, namun ternyata membawa dampak bagi kehidupan berumah tangga (Afriyanti, dkk. 2016)

Angka kejadian disfungsi seksual wanita di setiap negara bisa berbedabeda. Di Indonesia, Imronah (2011) dengan menggunakan instrumen FSFI menemukan bahwa kasus disfungsi seksual pada kaum wanita di Bandar Lampung mencapai $66,2 \%$. Jika angka-angka disfungsi seksual wanita di Turki (48,3\%), Ghana 72,8\%), Nigeria (63\%), dan Indonesia $(66,2 \%)$ itu dirata-ratakan kita dapatkan angka prevalensi sebesar 58,04\%. Itu artinya lebih dari separuh kaum wanita di dalam suatu negara berpotensi mengalami gangguan fungsi seksual. Dengan prevalensi sebesar itu wajar bila disfungsi seksual wanita tidak bisa dipandang remeh, karena menyangkut kualitas hidup lebih dari separuh populasi wanita (Sutyarso, 2011).

Pada Diagnostic and Statistic Manual version IV (DSM IV) dari American Phychiatric Assocation, dan International Classification of Disease-10 (ICD-10) dari WHO, disfungsi seksual wanita ini dibagi menjadi empat kategori yaitu gangguan minat/keinginan seksual (desire disorders), gangguan birahi (arousal disorder), gangguan orgasme (orgasmic disorder), dan gangguan nyeri seksual (sexual pain disorder). Penelitian yang dilakukan oleh Guleroghi dan Besen di Turki bahwa semakin rendah pendidikan seseorang maka semakin rendah pula total skor dari kuesioner FSFI yang didapatkan. Sedangkan berdasarkan jumlah paritas sebelumnya, didapatkan hasil semakin sedikit jumlah paritas maka semakin besar kejadian disfungsi seksual.

Data yang penulis dapatkan dari Dinas Kesehatan Kota Bukittinggi bahwa Puskesmas di Bukittinggi berjumlah 7 buah puskesmas yang tersebar di tiga kecamatan yaitu kecamatan guguk panjang memiliki 2 buah puskesmas yaitu Puskesmas Guguk Panjang dan Puskemas Perkotaan Rasimah Ahmad, di Kecamatan Aur Birugo Tigo Baleh memiliki 1 buah puskesmas yang bernama Puskesmas Tigo Baleh, di Kecamatan Mandiangin terdapat 4 buah puskesmas yaitu Puskesmas Mandiangin, Nilam Sari, Gulai Bancah dan Plus Mandiangin. 
Data awal dari Dinas Kesehatan Kota Bukittinggi menyatakan, jumlah sasaran Ibu Hamil pada bulan Januari di 7 Puskesmas Bukittinggi tahun 2019 yaitu ibu hamil berjumlah 2.418 orang ibu hamil. Peneliti akan melakukan penelitian di ke-7 puskesmas tersebut dimana jumlah ibu hamil Trimester I pada Masa Kehamilan Primigravida yaitu 41orang.

Survei awal yang penulis lakukan pada pada hari Senin tanggal 11 Februari 2019 pada 10 orang ibu hamil Trimester I pada Masa Kehamilan Primigravida melalui pengisian kuesioner Pengetahuan dan Female Sexual Function Index (FSFI) di wilayah kerja Puskesmas

\section{METODE PENELITIAN}

Desain yang digunakan dalam penelitian ini adalah deskriptif dengan pendekatan Cross Sectional. Penelitian ini telah dilaksanakan di wilayah kerja Puskesmas Kota Bukittinggi. Waktu penelitian ini dimulai dari 25 Maret - 21 Juni 2019. Pengumpulan data dilaksanakan dari tanggal 18-28 Februari 2019. Populasi dari penelitian ini adalah ibu hamil trimester I yang sedang dalam masa kehamilan primigravida yang bertempat tinggal di Kota Bukittinggi. Jumlah Populasi adalah 41 orang ibu hamil.

Kriteria inklusi pada penelitian ini adalah Ibu hamil primigravida trimester I yang berada di wilayah kerja puskesmas Kota Bukittinggi, kota Bukittinggi. Hasil survey awalnya yaitu didapatkan 8 orang ibu hamil kurang mengetahui tentang seksualitas dalam kehamilan, 7 orang ibu hamil yang mengalami penurunan dorongan seksual, 4 orang ibu hamil merasa tidak puas dan 2 ibu hamil mengalami ketidaknyamanan atau rasa nyeri saat berhubungan seksual dengan pasangannya. Bertolak dari pernyataan tersebut maka penulis tertarik untuk melakukan penelitian tentang Hubungan Pengetahuan dan Tingkat Kecemasan pada Kehamilan Primigravida terhadap Fungsi Seksual di Kota Bukittinggi Tahun 2019.

Ibu hamil yang dapat berkomunikasi dengan baik, Ibu hamil trimester I yang sedang dalam masa kehamilan primigravida, Ibu hamil yang bersedia menjadi responden. Kriteria Ekslusi dalam penelitian ini adalah Ibu hamilyang tidak bersedia menjawab kuesioner, Semua ibu hamil trimester I yang sedang dalam masa kehamilan primigravida pada saat berkunjung ia sedang bekerja atau tidak berada ditempat, Ibu hamil yang tidak bersedia menjadi responden. Alat pengumpulan data pada penelitian ini adalah kuesioner dan wawancara. Sumber data yang digunakan adalah data primer dan sekunder. Analisis data yang digunakan adalah analisis univariat dan bivariat. 


\section{HASIL DAN PEMBAHASAN}

Tabel 1

Distribusi Frekuensi Pengetahuan Pada Ibu Hamil Primigravida Dengan Fungsi Seksual Di Kota Bukittinggi

\begin{tabular}{ccc} 
Pengetahuan & f & \% \\
\hline Rendah & 19 & 46,3 \\
Tinggi & 22 & 53,7 \\
\hline Jumlah & 41 & 100 \\
\hline
\end{tabular}

Berdasarkan tabel 1 diatas, maka didapatkan hasil dari 41 orang responden yang diteliti, sebanyak 19 orang $(46,3 \%) \quad$ responden pengetahuan rendah.

Pengetahuan ibu yang tinggi tentang seksualitasnya maka ibu pasti tahu bahwa sebenarnya berhubungan seksual selama kehamilan ibu sehat dan normal itu diperbolehkan. Dikatakan sehat dan normal jika ibu tidak ada riwayat keguguran, melahirkan prematur, penyakit infeksi menular seksual, plasenta previa, kehamilan kembar dan perdarahan setelah berhubungan intim (Hartuti, 2010).

Penelitian ini sejalan dengan penelitian yang dilakukan oleh Hanum Masayu di Rumah Sakit Satiti Kertosono Nganjuk Jawa Timur dimana terdapat 26 responden atau $86,67 \%$ memiliki pengetahuan baik dan 4 responden atau 13,33\% memiliki pengetahuan kurang. Penelitian ini juga sejalan dengan penelitian Martini dan Setiyani dimana didapatkan dari 40 responden pengetahuan ibu tentang hubungan seksual selama kehamilan di Puskesmas Grobogan dikategorikan baik sebanyak $50 \%$, cukup $15 \%$, dan kurang $36 \%$.
Menurut asumsi peneliti, tingginya pengetahuan responden disebabkan adanya keinginan responden untuk membaca dan mencari tahu informasi seputar seksualitas. Dari penelitian ini pengetahuan seksualitas ibu hamil trimester I yang tinggi inilah yang membuktikan bahwa ibu tersebut sangat memperhatikan kesehatan reproduksinya agar ibu tahu selama kehamilan ternyata diperbolehkan melakukan hubungan seksual serta tahu posisi yang nyaman untuk ibu berhubungan seksual selama hamil. Dari penelitian yang penulis lihat pun responden tersebut memang ibu yang bisa dikatakan ibu modern yang sudah bisa mengakses informasi sehingga wawasan pengetahuan ibu menjadi lebih, Sedangkan hasil penelitian yang menunjukkan ibu hamil trimester I memiliki pengetahuan yang rendah mungkin disebabkan karena faktor lingkungan yang kurang, ibu mendapatkan informasi yang salah tentang seksualitas selama hamil, ibu masih percaya mitos yang beredar turun temurun dari keluarga atau teman, dan dari sisi ibu hamil sendiri masih kurangnya kesadaran untuk mencari tahu tentang pentingnya pengetahuan seksualitas selama kehamilan. 
Tabel 2

Distribusi Frekuensi Tingkat Kecemasan Pada Ibu Hamil Primigravida Dengan Fungsi Seksual Di Kota Bukittinggi

\begin{tabular}{ccc}
\hline Tingkat Kecemasan & $\mathbf{f}$ & \% \\
\hline Ada Kecemasan & 32 & 78,0 \\
Tidak Ada Kecemasan & 9 & 22,0 \\
\hline Jumlah & 41 & 100 \\
\hline
\end{tabular}

Berdasarkan tabel 2, maka dari 41 orang responden yang diteliti didapatkan sebanyak 32 orang responden atau $78 \%$ mengalami kecemasan.

Menurut Stuart (2008), respon cemas seseorang tergantung pada kematangan pribadi, pemahaman dalam menghadapi tantangan, harga diri, dan mekanisme pertahanan diri yang digunakan untuk mengatasi kecemasannya antara lain dengan menekan konflik dan tak mau memikirkan hal yang kurang menyenangkan dirinya.

Penelitian ini sejalan dengan penelitian yang dilakukan oleh Nurymayasari di Wilayah Kerja Puskesmas Kesamben Kabupaten Jombang dimana terdapat 3 responden atau $7,9 \%$ tidak mengalami kecemasan dan 35 responden atau 92,1\% mengalami kecemasan. Penelitian ini juga sejalan dengan penelitian Astuti (2010) dan Sulistyorin (2007) yang berjudul Pengaruh Peran Suami terhadap Tingkat Kecemasan Ibu Hamil bahwa dari 80 responden sebanyak $53,75 \% \quad$ mengalami kecemasan.

Menurut peneliti banyaknya ibu hamil yang mengalami kecemasan karena responden yang peneliti teliti itu adalah ibu primigravida dimana ibu mendapat informasi yang terbatas di awal kehamilannya dan belum punya banyak pengalaman serta timbul kecemasan dalam melakukan hubungan seksual selama hamil. Ibu juga mempercayai mitosmitos yang beredar seperti kalau hamil satu sampai tiga bulan itu tidak diperbolehkan melakukan hubungan seksual nanti bisa keguguran. Ibu yang tidak mengalami kecemasan saat hamil, dikarenakan ibu mempunyai pengetahuan tinggi tentang kehamilannya, ibu juga sering menggali informasi seputar kehamilannya, dan ibu memang pribadi yang tidak mudah cemas atau bisa mengontrol rasa khawatir atau cemasnya dengan caranya sendiri.

Tabel 3

Distribusi Frekuensi Fungsi Seksual Pada Ibu Hamil Primigravida Dengan Fungsi Seksual Di Kota Bukittinggi

\begin{tabular}{ccc}
\hline Fungsi Seksual & $\mathbf{f}$ & $\boldsymbol{\%}$ \\
\hline Disfungsi & 24 & 58,5
\end{tabular}




\begin{tabular}{ccc} 
Nornal & 17 & 41,5 \\
\hline Jumlah & 41 & 100
\end{tabular}

Berdasarkan tabel 3 diatas, dari 41 orang responden yang diteliti didapatkan sebanyak 24 orang responden atau 58,5\% mengalami disfungsi seksual.

Fungsi seksual dipengaruhi oleh usia, pengetahuan, penyakit kronik, hormon, kehamilan dan persalinan. Gangguan fungsi seksual dapat mempengaruhi kualitas hidup wanita dan memiliki efek negatif pada rasa percaya diri. Dalam sebuah populasi umum wanita dapat mengalami gangguan fungsi seksual sebesar 40$50 \%$ selama hidupnya (Pangkahila, 2018).

Penelitian ini sama dengan penelitian Alessandra $\mathrm{P}$ dkk ditemukan prevalensi gangguan fungsi seksual rata-rata $46,6 \%$ pada trimester pertama dan sama halnya dengan penelitian Evelyn I dkk dimana terdapat $85,7 \%$ ibu hamil trimester I yang mengalami disfungsi seksual. Penelitian ini juga sejalan dengan penelitian Aydin Cayonu dkk
2015 dan Gulero di Turki yang menunjukkan disfungsi seksual $91,08 \%$ dan $63,4 \%$ terjadi pada ibu hamil.

Menurut peneliti fungsi seksual ibu hamil muda dapat mengalami gangguan karena ibu mengalami mual muntah yang dapat membuat ibu tidak mau melakukan aktivitas seksual serta ibu primigravida biasanya takut melukai janinnya atau terjadi, ibu dan suami tidak terlalu terbuka tentang apa yang dirasakan nya saat berhubungan seksual. Fungsi seksual yang terganggu juga dapat menyebabkan kurang puasnya hubungan suami istri yang terjalin sehingga dapat memicu keretakan rumah tangga. Ibu hamil yang memiliki fungsi seksual yang normal pasti sangat mempunyai keterbukaan pada suaminya sehingga apapun masalah yang suami istri itu hadapi saat berhubungan seksual bisa teratasi dan ibu tahu posisi yang baik selama hamil.

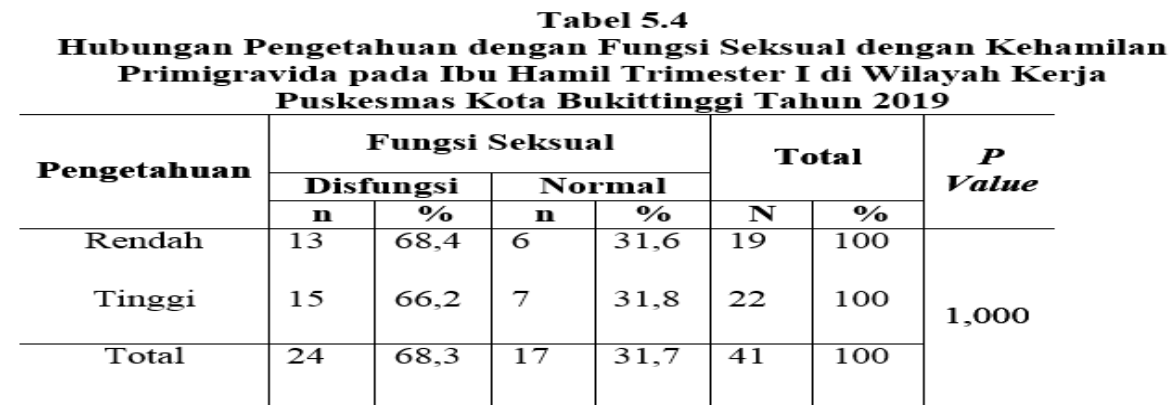

Berdasarkan tabel 4 didapatkan, dari 19 orang responden yang memiliki pengetahuan rendah, 13 diantaranya mengalami disfungsi seksual dan dari 22 orang responden yang memiliki pengetahuan tinggi, 15 diantaranya mengalami disfungsi seksual. Setelah dilakukan uji statistik Chi-Square didapatkan hasil $p$ value $=1,000(\mathrm{p}>0,05)$, sehingga dapat disimpulkan tidak terdapat hubungan bermakna antara pengetahuan dengan fungsi seksual. 
Pengetahuan ibu hamil tentang seks merupakan salah satu faktor yang penting untuk dikaji dalam kehamilan karena dari tingkat pengetahuan akan mempengaruhi kecemasan ibu hamil. Dimana produksi hormon kortisol berlebihan akan meningkatkan tekanan darah dan emosi tidak stabil (Wals, Linda V, 2008). Fungsi seksual dipengaruhi oleh usia, pengetahuan, penyakit kronik, hormon, kehamilan dan persalinan. Gangguan fungsi seksual dapat mempengaruhi kualitas hidup wanita dan memiliki efek negatif pada rasa percaya diri. Dalam sebuah populasi umum wanita dapat mengalami gangguan fungsi seksual sebesar 40-50\% selama hidupnya (Pangkahila, 2018).

Penelitian ini sejalan dengan penelitian yang dilakukan oleh Guierough dan Beser di Turki bahwa semakin rendah pendidikan seorang maka makin rendah skor dari kuesioner FSFI yang didapatkan (Pangkahila, 2018).
Menurut peneliti tidak terdapat hubungan yang bermakna antara pengetahuan dengan fungsi seksual ibu hamil karena belum tentu ibu yang berpengetahuan tinggi dapat mengontrol gangguan seksual yang disebabkan oleh hormon akibat mual muntah atau perubahan mood yang dialaminya. Ibu yang pengetahuan nya tinggi tapi pengalaman dalam hal seksual nya tabu maka itu bisa menjadi penyebab disfungsi seksual yang dialami ibu atau malah sebaliknya. Ibu yang kurang terbuka dan kurang berkomunikasi mengenai seksualitas dgn suaminya pun juga bisa menjadi penyebab disfungsi seksual yang dialaminya. Sedangkan ibu yang berpengetahuan rendah dan mengalami disfungsi seksual dikarenakan ibu tidak tahu posisi berhubungan seksual yang baik dilakukan selama hamil. Ketidaktahuan ibu disebabkan kurangnya kesadaran ibu untuk mencari informasi dan salah dalam mendapatkan informasi.

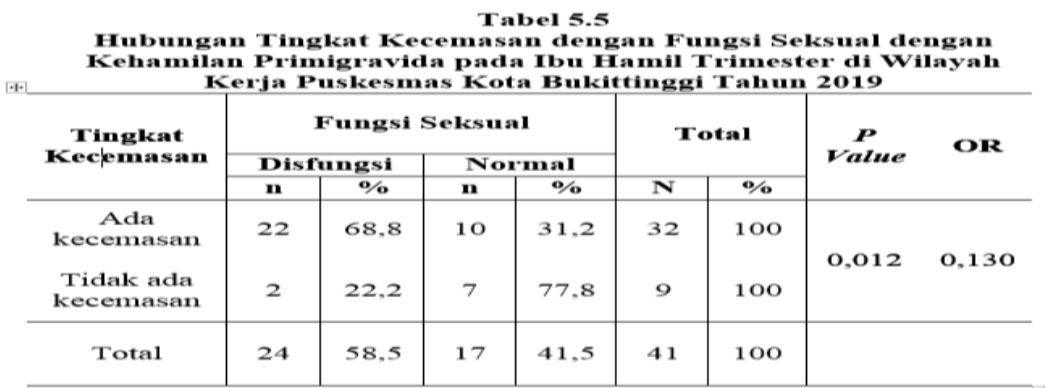

Berdasarkan tabel 5 didapatkan dari 32 orang responden mengalami kecemasan, 22 diantaranya mengalami disfungsi seksual dan dari 9 orang responden yang tidak mengalami kecemasan, 2 diantaranya mengalami disfungsi seksual. Setelah dilakukan uji statistik Chi-square didapatkan hasil $p$ value $=0,012(\mathrm{p}$ $<0,05)$, sehingga dapat disimpulkan terdapat hubungan bermakna antara tingkat kecemasan dengan fungsi seksual dengan OR 0,130 yang artinya kecemasan tidak beresiko.

Kecemasan merupakan kondisi perasaan yang tidak menyenangkan yang merujuk pada rasa khawatir, takut, was-was yang ditimbulkan oleh pengaruh ancaman atau gangguan terhadap sesuatu yang belum terjadi dan sangat mengganggu aktivitas (Herman, Ade, 2011). Menurut Leiblum dan Wiegel ada empat faktor yang 
mempengaruhi gangguan desire dan arousal seorang wanita, yaitu emosi negatif, body image, kecemasan, serta mitos dan kesalahpahaman (Valani, Rahamanisa dkk, 2018).

Penelitian ini sesuai dengan teori Sagiv (2012) dimana selama hamil wanita takut berhubungan seksual karena kecemasan yang timbul akibat perubahan fisik dan psikologis ibu hamil seperti kelelahan, mual, nyeri selama aktivitas seksual, sakit pinggang, sensitifitas payudara, perubahan hormon serta mood dan takut membahayakan janin sehingga ibu memilih untuk tidak berhubungan seksual. Penelitian ini sejalan dengan penelitian yang dilakukan pada 298 orang ibu hamil di Cina, $80 \%$ ibu khawatir atau cemas apabila melakukan hubungan seksual selama kehamilan akan memberi efek negatif pada janinnya sehingga enggan melakukan aktivitas seksual (Pasaribu, Ramadhan dkk, 2016). Pada jurnal review yang dilakukan Christine Dubkel Schetter dan Lynlee Tanner menyatakan ibu hamil trimester pertama merasa cemas, khawatir, takut, dan panik terhadap kehamilannya sehingga

\section{SIMPULAN}

Berdasarkan penelitian yang dilakukan didapatkan hasil penelitian sebagai berikut :

1. $53,7 \%$ ibu pengetahuan tinggi pada Kehamilan Primigravida Trimester I di Kota Bukittinggi Tahun 2019.

2. $78 \%$ mengalami kecemasan pada Kehamilan Primigravida Trimester I di Kota Bukittinggi Tahun 2019.

3. $58,5 \%$ ibu mengalami disfungsi seksual pada Kehamilan Primigravida Trimester I di Kota Bukittinggi Tahun 2019. berpengaruh terhadap kepuasan seksual (Ramadani, Sudarmiati 2013).

Menurut peneliti terdapat hubungan yang bermakna antara tingkat kecemasan dengan fungsi seksual karena kecemasan timbul akibat mual muntah yang ibu alami pada awal kehamilan sehingga mempengaruhi hormon, mood, dan emosi yang dapat menurunkan fungsi seksuanya seperti mengurangi minat ibu untuk melakukan hubungan seksual, mengurangi kepuasan saat berhubungan seksual. Kecemasan juga dapat membuat ibu tidak nyaman serta merasa lelah saat berhubungan seksual. Kecemasan lainnya dialami ibu karena ibu masih belum memiliki banyak pengalaman tentang kehamilan dan seksualitas. Sedangkan ibu yang tidak cemas tetapi mengalami disfungsi seksual dikarenakan ibu hanya masih mempercayai mitos yang beredar seperti jika hamil 1-3 bulan itu tidak diperbolehkan berhubungan seksual dulu sehingga saat suami merangsang ibu untuk melakukan hubungan seksual, ibu sama sekali tidak tertarik.

4. Tidak terdapat hubungan yang bermakna antara pengetahuan dengan fungsi seksual pada Kehamilan Primigravida Trimester I di Kota Bukittinggi Tahun 2019 ( $p$ value $=1,000 ;>$ 0,05 ).

5. Terdapat hubungan yang bermakna antara tingkat kecemasan dengan fungsi seksual pada Kehamilan Primigravida Trimester I di Kota Bukittinggi Tahun 2019 ( $p$ value $=0,012 ;<0,05$ dan OR = $0,130)$. 


\section{REFERENSI}

Afriyanti, Yati, dan Anggi Pratiwi. 2016. Seksualitas dan Kesehtan Reproduksi Perempuan. Jakarta:Rajawali Pers.

Allan, Walker. 2012. "Pola Makan Sehat Saat Hamil". Jakarta:PT.Bhuana Ilmu Populer.

American Psychiatric Association Diagnostic and Statical Manual of Mental Disorders (DSM-V), Edisi ke-5, USA:American Association. 2013.

Arikunto, Suharsimi. 2010. Prosedur Penelitian. Jakarta:Rineka.

Aydin, Mustafa, dkk. 2015. Comparison of Sexual Function in Pregnant and Non- Pregnant Women. Journal Turkey Vol 12 No 05. Turkey. Diakses tanggal 10 Februari 2019.

Budiarti, dkk. 2017. Studi Fenomenologi: Pengalaman Seksualitas Perempuan Selama Masa Kehamilan di Surabaya. STIKes Hang Tuah. Jawa Timur. 2017. Diakses tanggal 10 Februari 2019.

Cahyono, eko. 2010. Kecemasan Primigravida Menghadapi Persalinan. http://Organisasi.org/kecemas an-primigravida-menghadapipersalinan melahirkan.com (diakses tanggal 15 Februari 2019)

Desi, Rahma. 2014. Gambaran Pengetahuan, Sikap, dan Status Ekonomi Ibu Hamil tentang Kebutuhan Nutrisi selama Kehamilan di Puskesmas Rasimah Ahmad Bukittinggi. STIKes Fort De Kock. Bukittinggi. Diakses tanggal 05 Februari 2018.

Dinas Kesehatan Kota Bukittinggi, 2019. Profil Kesehatan Kota Bukittinggi Tahun 2019.

Eisenberg. 2006. Didownload tanggal 18 Februari 2019. http://digilib.unimus.ac.id

Fajrin, Fitriana. 2016. Hubungan Pengetahuan Ibu Hamil tentang Seks selama Kehamilan dengan Melakukan Hubungan Seks selama Kehamilan. Universitas Islam Lamongan. Diakses tanggal 10 Februari 2019.

Getstenberger, Ep, dkk. 2010. Sexual Desire And The Female Sexual Function Index (FSFI): A Sexual Desire Cutpoint For Clinical Interpretion Of The FSFI In Women With and Without Hypoactive Sexual Desire Disorder. The Journal of Sexual Midwife. 2010.

Hapsari dan Sudarmiati, 2011. Pengalaman Seksualitas Ibu 
Hamil di Puskesmas Pondok Aren Tangerang. Jurnal Ners, Vol.6 No.1. Program Studi Ilmu Keperawatan Fakultas Kedokteran Universitas Diponegoro. Semarang. Diakses tanggal 10 Februari 2019.

Jones, D. 2001. Dasar-dasar Obstetri dan Ginekologi. Jakarta:Arcan.

Kissanti, 2003. Seksual yang Aman dalam Masa Kehamilan. http://bidanku.com/index.php ?/Seks-Selama-KehamilanAmankah diakses tanggal 15 Februari 2019

Manuaba, Ida Ayu Chandranita, dkk. 2012."Memahami Kesehatan Reproduksi Wanita". Jakarta:EGC.

Maritalia. 2012. Kehamilan. Pustaka pelajar. Yogyakarta.

Maryuni, Anik. 2013. Biologi Reproduksi dalam Kebidanan. Jakarta:Trans Info Media.

Mubasyiroh, Laelatul. 2010. Hubungan Tingkat Pengetahuan dengan

Kecemasan Ibu Hamil Primigravida tentang Hubungan Seksual Selama Kehamilan Di Puskesmas Kecamatan Jatibarang Kabupaten Brebes. Brebes. Diakss tanggal 10 Februari 219.

Munarriz, 2002. Seks Kehamilan. http://repository.usu.ac.id/bits tream/pdf diakses tanggal

10 Februari 2019 Murkoff, 2006.

Notoatmodjo, Soekidjo. 2010. "Metodologi Penelitian Kesehatan". Edisi Revisi. PT. Rineka Cipta. Jakarta: Human Reproduction.

Ramadani dan Sudarmiati. 2013. Perbedaan Tingkat Kepuasan Seksual pada Pasangan

Suami Isteri di masa Kehamilan. Jurnal

Keperawatan Maternitas Vol.2. Program Studi Ilmu Keperawatan Fakultas

Kedokteran Universitas Diponegoro. Semarang. Diakses tanggal 10 Februari 2019.

Rosen, Brown, Helman, dkk. 2016. The Female Sexual Function Index (FSFI): A

Multidimensional SeldReport Instrument for the Assessment of Female Sexual Function. Journal of Sex and Marital Therapy. University of Texas. 2016.

Saraswati dan Pangkahila. 2015. Gambaran Penurunan Dorongan Seksual pada Ibu Hamil di Puskesmas Denpasar Selatan II Tahun 2015. Directory Of Open Journals (DOAJ). Program Studi Pendidikan Dokter Fakultas Kedokteran Universitas Udayana. Bali. Diakses tanggal 15 Februari 2019.

Sarwono, Prawirohardjo. 2008. “Ilmu Kebidanan". Jakarta : 
Yayasan Bina Pustaka

Sarwono.

Wals, Linda. 2008. Seks Kehamilan.

http://repository.usu.ac.id/bits

tream/.pdf Diaksess

tanggal 13 Februari 2019

Windhu, Candra. 2009. "Disfungsi

Seksual". Yogyakarta:ANDI.

Wiknjosastro. 2002. Ilmu

Kebidanan. Yayasan Bina

Pustaka.

Prawirohardjo:Jakarta.

World Health Organization (WHO).

Defining Sexual Health.

http://www.who.int/reproduct

ivehealth/topics/sexual_healt

h/sh)definitions /en/

(diakses tanggal 10 Februari 2019).

World Health Organization (WHO). 2012. "Trends In Maternal Mortality". Geneva:World Health Organization.

Yogi, Etika Desi. 2016. Hubungan antara Pengetahuan Ibu Hamil dengan Tingkat

Kecemasan tentang

Hubungan Seksual Di BPS

Ny.S Desa Kemiri

Kecamatan Jenangan

Kabupaten Ponorogo. Jawa

Timur. Diakses tanggal 15 Februari 2019. 